and Einstein's mistress - intolerable.

These personal details illuminate fundamental issues: the link between Einstein's creativity and his emotional state, and why his marriage fell apart and his eldest son bore him a grudge. Even though there is no-one to hurt by such revelations, Pais decides that the reader should be spared them. Like Carl Seelig, he had greater access to Einstein's secrets than most other biographers, but perhaps he also felt so much a part of the family that he kept them to himself.

It is also telling that Pais pays special tribute to Helen Dukas, the woman who spent 27 years at Einstein's side while he faced threats ranging from oppressive media attention to the Nazis and the McCarthy investigation of supposed communists. She was liable to attack as "dung" any biographers who dared to shed light on Einstein's personal life.

The remaining chapters demonstrate that a collection of essays does not necessarily make a book. There is no fundamental unifying theme, although Pais is more comfortable moving away from Einstein's family life to his crank mail, his
Nobel prize and his relationship with religion, philosophy and the media. Pais diligently collates a wide range of information, uncovers some striking Einstein quotations that are as true today as 60 years ago, and crisply summarizes the various themes. I wish, however, there had been tougher editing: the main essay of the book, on Einstein and the press, reads too much like notes, some parts are dull (try, for instance, the section on: "The return home via three weeks in Spain") and the analysis too brief.

But much of my criticism reflects disappointment that Pais has not fulfilled our high expectations of the author of Subtle is the Lord. Some biographers are still attempting to research Einstein's story without coming within a mile of an archive, scholar or Einstein relative. The potboilers that result are totally outclassed by Einstein Lived Here. Scholarly, thoughtful and entertaining in parts - but quite unable to answer the Big Question.

Roger Highfield is science editor at The Daily Telegraph, and author with Paul Carter of The Private Lives of Albert Einstein (Faber, 1993/St Martin's, 1994).

\title{
Family values in signal transduction
}

\section{Alan Hall}

The G-Protein Linked Receptor FactsBook. By Steve Watson and Steve Arkinstall. Academic Press: 1994. Pp. 427. $£ 19.50, \$ 29.95$.

A RECENT article in Nature reported that only one in three genes emerging from the project to map the genome of the nematode worm Caenorhabditis elegans was similar to a previously known gene. This contrasts strikingly with the experience of those of us in the signal-transduction field where it seems almost inevitable that each new protein identified is either just one member of a larger family or at least contains a domain found in numerous other proteins. It's a struggle to understand much of this complexity and apparent functional redundancy, let alone remember all the names. However, all is not despair, except perhaps for those doing gene knock-outs, and there is some satisfaction to be gained from comparing families and superfamilies of related proteins, as it reveals the essential conservatism of evolution: making the most of a good idea.

Seven transmembrane receptors are a classic example of a 'good idea'; estimated to number in the thousands (well over a hundred are described in this book), their overall structures are highly conserved and they each generate an intracellular signal by first coupling to a GTP-binding protein. Even prokaryotes realized that the GTP-binding protein was a simple and effective way of controlling biochemical processes and an impressive array of regulatory proteins has evolved in eukaryotic cells based on this principle. The heterotrimeric G-protein family specifically couples seven transmembrane receptors to second messenger enzymes and more than 20 varieties have been found in mammalian cells. This FactsBook assembles the sequence, specificity and functional properties of the known seven transmembrane receptors and their associated $\mathrm{G}$ proteins. In addition, although they are not related structurally or functionally to each other, similar information is presented for the downstream second messengergenerating enzymes.

Compilations such as this are becoming increasingly necessary to bring order and accessibility to the vast amount of new information generated on protein function. This FactsBook is extremely well presented and referenced and is userfriendly. It will be an essential source of reference for anyone actively involved in signal transduction research.

Alan Hall is in the MRC Laboratory for Molecular Cell Biology and the Department of Biochemistry, CRC Oncogene and Signal Transduction Group, University College London, Gower Street, London WC1E 6BT, UK.

\section{New in paperback}

Space, Time and Man: A Prehistorlan's

Vlew by Grahame Clark. Canto (Cambridge University Press), £5.95, \$9.95. "A deep appreciation of our historical roots, seen in a very large frame" (Owen Gingerich,

Nature 358, 381; 1992).

Quantum Physics: Illusion or Reallty? by Alastair Rae. Canto (Cambridge University Press), $£ 4.95, \$ 8.95$. A clear introductory exploration of the theories on offer.

A Dancing Matrlx: How Sclence Confronts Emerging Viruses by Robin Marantz Henig.

Vintage, \$12. Now updated. The first edition of this book was described by

Beverley Griffin as "vital and

stimulating. . . once picked up, it is difficult to put down" (Nature 364, 201; 1993).

The Language of the Genes: Blology, History and the Evolutlonary Future. HarperCollins, £6.99. "This intelligent and informative book deserves to be read widely, since it provides a vivid demonstration of what a remarkable and fragile product of evolution our species is" (C. Wills, Nature 364, 113; 1993).

The Planets: Portraits of New Worlds by

Nigel Henbest. Penguin, £15, \$17.95.

"Lavishly illustrated in colour and the pictures are of the highest quality. . . an excellent, up-to-date, general introduction to space-age planetary astronomy" (David Hughes, Nature 359, 684; 1992). The Diversity of Life by Edward $\mathrm{O}$. Wilson. Penguin, $£ 7.99$. "A deft and thoroughly successful mixture of information and prophecy. . . a great and fit work destined to survive and thrive well into the next millennium. . Wonderfui writing" (Stephen Jay Gould, Nature 361, 311; 1993).

Elght Little PIggles: Reflections In Natural History by Stephen Jay Gould. Norton/ Penguin, \$10.95. "A lovely mixture of bizarre facts, nice arguments, clever insights into the workings of evolution and a quality of writing that can make your skin prickle. . . Gould has given us a feast" (Bryan Clarke, Nature 362, 656; 1993).

\section{Who's who In science}

Two newly revised scientific bibliographical reference guides have just been published. Blographlcal Encyclopedia of Scientists edited by J. Daintith, S. Mitchell, E. Toothill and D. Gjertsen (2nd edn; 2 vols; pp. 1,075; 15 contributors) contains a main biography section of some 2,000 entries, each of about 300 words; shorter sections listing chronologies of scientific discoveries, scientific institutions, and influential books and papers; and name and subject indexes. Institute of Physics Publishing, £120, \$190. Collins Blographical Dictionary of Sclentists edited by Trevor Williams (4th edn; pp. 602; 60 contributors) provides generally longer accounts of more than 1,300 individuals each with bibliographical details for further reading. It ends with chronological listings of Nobel laureates and anniversaries, an appendix of names and a subject index. HarperCollins, $£ 25$. 